\title{
Eruption crisis at Kilauea Caldera (Big Island of Hawaii, USA)
}

\author{
Bulletin of Volcanology Editor-in-Chief ${ }^{1}$
}

Published online: 16 July 2018

(C) Springer-Verlag GmbH Germany, part of Springer Nature 2018

Following the opening of new eruptive fissures low on the east rift zone of Kilauea volcano, Kilauea's summit underwent deflation, the lava lake began to recede, and on 17 May, an explosive event sent ash to a height of $9 \mathrm{~km}$. As a result, Bulletin of Volcanology has opened access to four scientific papers that provide insight into past subsidence events and explosive activity at Kilauea caldera.

Delaney and McTigue examined the 1960 collapse of Kilauea's caldera. Like today's subsidence, this occurred during and after an effusive event on the lower east rift zone. Subsidence, to an eventual depth of $50 \mathrm{~m}$, was continuous and was associated with seismic activity. Delaney and McTigue concluded that the volume of subsidence was closely related to the volume of magma withdrawn from the reservoir immediately below the caldera.

In their 1990 study, McPhie and colleagues examined the famous Keanakakoi ash deposit; it is famous because it is associated with an explosive eruption that killed a party of Hawaiian warriors travelling near the caldera in 1790. McPhie and colleagues demonstrated that the opening phase was phreatomagmatic - that is, an explosion caused by the interaction of magma and water. It is believed that activity continued for several months and occurred at a time when the caldera was very deep.

Dvorak, on the other hand, believed that a phreatic eruption caused Kilauea's explosive eruption of May 1924. Phreatic eruptions are triggered by the interaction of water and hot rock. This eruption was preceded by rapid draining of a lava lake and transfer of a large volume of magma from the summit reservoir to the east rift zone, leaving the surface rocks at a raised temperature. Dvorak explains that,

Bulletin of Volcanology Editor-in-Chief andrew.harris@uca.fr

1 Bulletin of Volcanology Editorial Office, Laboratoire Magmas et Volcans, Université Clermont Auvergne, Aubière,

Clermont-Ferrand, France
"This lowered the magma column, which reduced hydrostatic pressure beneath Halemaumau and allowed groundwater to flow rapidly into areas of hot rock, producing a phreatic eruption".

Instead, Orr and Rea examined the type of gas jetting activity that we had become more familiar with during Kilauea's eruption that had been relatively stable since 1983. That is until the events in Puna earlier in May caused the situation to radically change (see the preceding Bulletin of Volcanology press release of 09 May 2018). Termed "gas pistoning", this more benign type of (exceedingly mild) "explosive" activity involved the cyclic rise and fall of a lava surface within a volcanic vent or lava lake. This is associated with the accumulation of a layer of gas just below the lava surface to push the surface upwards, followed by release (as the jet) during which the surface falls and after which the cycle begins again.

Founded in 1922, Bulletin of Volcanology is the official journal of the International Association of Volcanology \& Chemistry of the Earth's Interior (IAVCEI). The Bulletin publishes papers on volcanoes, their products, their eruptive behaviour, and their hazards (https://link.springer.com/ journal/445).

Open access to the six papers released here can be found at:

Delaney PT and McTigue DF (1994)

Volume of magma accumulation or withdrawal estimated from surface uplift or subsidence, with application to the 1960 collapse of Kilauea Volcano

Link https://link.springer.com/article/10.1007/BF00302823

McPhie J, Walker GPL, and Christiansen RL (1990)

Phreatomagmatic and phreatic fall and surge deposits from explosions at Kilauea volcano, Hawaii, 1790 A.D.: Keanakakoi Ash Member

Link https://link.springer.com/article/10.1007/BF00302047 
Dvorak JJ (1992)

Mechanism of explosive eruptions of Kilauea Volcano, Hawaii

Link https://link.springer.com/article/10.1007/ BF00430777
Orr TR and Rea JC (2012)

Time-lapse camera observations of gas piston activity at $\mathrm{Pu}^{`} \mathrm{u}$ ' $\overline{\mathrm{O}}^{`} \mathrm{o}$, Kīlauea volcano, Hawai' $\mathrm{i}$

Link https://link.springer.com/article/10.1007/s00445012-0667-0 